Acta Veterinaria (Beograd), Vol. 63, No. 5-6, 525-536, 2013.

DOI: 10.2298/AVB1306525M

UDK: $579.861 .2+351.774 .7: 636.234+618.19-002$

\title{
EFFICIENCY EVALUATION OF A BIVALENT VACCINE IN THE PROPHYLAXIS OF MASTITIS IN COWS
}

\author{
MAGAŠ V, VAKANJAC SLOBODANKA, PAVLOVIĆ V, VELEBIT B, MIRILOVIĆ M, MALETIĆ M, \\ ĐURIĆ M and NEDIĆ SVETLANA
}

University of Belgrade, Faculty of Veterinary Medicine, Belgrade, Serbia

(Received 31 ${ }^{\text {st }}$ March 2013)

Mastitis in cows represents one of the most actual problems in intensive dairy production. The longtime different approaches to the treatment of mastitis have not offered a suitable solution, and the problem of mastitis is still present and acute. Prevention of pathogen penetration into the mammary gland, its colonization and multiplication impose a constant need for regular inspections of milk, as well as preventive and therapeutic measures to reduce the incidence of mastitis. Studies in the field of vaccination of ruminants against mastitis pathogens suggest a limited success in obtaining significant results in immunoprophylaxis. Considering the results of other researchers and our own research, and bearing in mind the problems mastitis caused by Staphylococcus aureus and Streptococcus agalactiae represent, the aim of this study was the preparation and testing of an indigenous vaccine prepared with two stable strains, SAU 7 (S. aureus) and SAG 3 (Str.agalactiae). The dose was $5 \mathrm{~mL} / \mathrm{cow}$ and consisted of inactivated bacterial S. aureus SAU 7 cells in a concentration of $1 \times 10^{10} \mathrm{cfu} / \mathrm{mL}$ and Str. agalactiae SAG 3 in a concentration of $4 \times 10^{9} \mathrm{cfu} / \mathrm{mL}$. The number of somatic cells in the milk samples during the whole study period was higher in vaccinated cows in both groups compared with the control, but this difference was not statistically significant. The concentration of immunoglobulin IgG in the milk of vaccinated cows was significantly higher than the concentration of this class of proteins in the milk of unvaccinated cows.

Key words: mastitis, Staphylococcus aureus, Streptococcus agalactiae, vaccines 


\section{INTRODUCTION}

Immunoprophylaxis against mastitis pathogens during the '70ties was based on polyvaccines, which consisted of immunogenic strains of staphylococci, streptococci and coliform bacteria, exotoxins and endotoxins. Polyvalent vaccines have not proven to be successful, and their production was abandoned in favor of monovalent vaccines, which gave much better results. The vaccine against Staphylococcus aureus contains inactive S. aureus cells (Giraudo, 1997; Hoedermaker, 1999), as well as Str. agalactiae cells (Giraudo, 1997). A large number of studies indicate that in order to obtain an improved inactivated vaccine alpha and beta toxoids are added to $S$. aureus, as well as fragments of its capsule (Calzolari, 1997; Watson, 1996). Keskin et al. (2007) described the effects of a commercial vaccine which contained inactivated strains of $S$. aureus TC5, $S$. aureus TC8, E. coli, Str. agalactiae, Str. uberis, S. pyogenes, P. aeruginosa and A. pyogenes. A highly specific stable vaccine, produced in Tornau, was for the first time used for the immunization of a herd in Germany (Hoedemaker, 1999). One vaccine dose measured $3.8 \times 10^{8} \mathrm{cfu} / \mathrm{mL}$ formalin inactivated $S$. aureus cells. No statistical significance in mastitis incidence between groups was established, nor was for the number of SCC in the milk samples. Extensive testing was conducted by Edinger (2000) who examined the vaccine prepared from two strains of $S$. aureus, previously inactivated with formalin. The vaccine measured a total bacterial cell count $(\mathrm{TBC} / \mathrm{mL})$ in a concentration of $1 \times 10^{11}$ and $8.8 \times 10^{10}$ of the other strain. The somatic cells count (SCC) in the milk was lower in the vaccinated group, but was statistically significant at the third sampling. A new approach in the preparation and application of vaccines was given by Carter (2003), the vaccine contained human cytomegalovirus on whose plasmid DNA out a direct expression of the Green fluorescent Staphyloccocal protein (GFP) was carried. The effects of the vaccine on the increase of antibodies against $S$. aureus which consisted of a polysaccharide capsule type 5 (T5), 8 (T8) and 336 (T336), were described by Lee (2005) in his work. The experiment described by Abubakar (2006) indicates that the group of rats vaccinated and revaccinated with an inactivated vaccine against Str. agalactiae exhibited a higher antibody titer compared to the group which received a single vaccine dose. The vaccine was prepared with a formalin inactivated strain of Str. agalactiae $\left(1 \times 10^{9} / \mathrm{mL}\right)$ and applied to rats subcutaneously in a dose of $0.2 \mathrm{~mL}$. In a study Vakanjac et al. (2008) described the preparation of a vaccine applied in a dose of $5 \mathrm{~mL}$ ( $S$. aureus JR 3 in a quantity of $1 \times 10^{10} \mathrm{cfu} / \mathrm{mL}$, $5 \mathrm{mg} \mathrm{SM}$ capsule $S$. aureus 2286 strain). Cows were vaccinated two months and re-vaccinated one month before the expected partum. There was no statistical significance in the number of SCC values of the control and vaccinated groups. However, a statistically significant difference was found in the values of the levels of antibodies in immunized cows (0.697 OD) compared to the control group ( 0.438 OD). Ahmar (2008) described the preparation of a bivalent vaccine against mastitis caused by $S$. aureus and Str. agalactiae. The titre of specific anti streptococcal and 
anti staphylococcal antibodies of the vaccinated group of rabbits was significantly increased compared with the control group. The vaccine prepared by Leitner (2011) contained part of the membrane of the surface protein rTRAP (recombinant Target RNAIIl Activating Protein) and it is an integral component of protein 167 AA, being a landmark of pathogenic staphylococcal strains. Antibody levels in the first three months after vaccination were significantly higher in the experimental group of cows, as opposed to the number of SCC, which was higher in the control group. Chen (2012) prepared a staphylococcal enterotoxin A (rSEA) recombinant vaccine and used as a carrier polylastic-co-glycolic acid (PLGA) microparticles. Test results showed a strong humoral response to increasing concentrations of antibodies against rSEA and increased survival of mice infected with lethal doses of $S$. aureus.

\section{MATERIAL AND METHODS}

Vaccine preparation - The vaccine was prepared with two autochthonous strains which have displayed distinct biochemical features of $S$. aureus SAU 7 and Str. agalactiae SAG 3. Both these strains were seeded on Brain-Heart Infusion (Serva). The prepared $5 \mathrm{~L}$ Brain-Heart Infusion was seeded with the isolated $S$. aureus SAU 7 strain. The so seeded media was incubated for $24 \mathrm{~h}$ at $37^{\circ} \mathrm{C}$. After incubation to the nutrient agar were added $0.4 \% \mathrm{vol} / \mathrm{vol}$ formalin and once again incubated for $24 \mathrm{~h}$. After inactivation of the microorganism with formalin the culture was centrifuged at $7,000 \mathrm{rpm}, 20$ minutes, at $4^{\circ} \mathrm{C}$. The inactivation procedure was tested by seeding on blood agar and incubation at $37^{\circ} \mathrm{C}$ for $24 \mathrm{~h}$. Lack of bacterial growth and hemolysis confirmed that the culture was successfully inactivated. After centrifugation the supernatant was discarded and the sediment resuspended in $0.9 \% \mathrm{NaCl}, \mathrm{pH} 7.0$. The resuspended sediment represented the first component of the vaccine.

The same procedure was repeated with the Str. agalactiae SAG 3 strain, and the resuspended sediment was used as the second component of the vaccine. In the resuspended sediments $0.4 \% \mathrm{vol} / \mathrm{vol}$ formalin, $0.001 \% \mathrm{wt} / \mathrm{vol}$ timerasol and $3.5 \% \mathrm{wt} / \mathrm{vol}$ carrier aluminium hydroxide, were added.

The dose of the vaccine was $5 \mathrm{~mL} / \mathrm{cow}$, containing inactivated bacterial S. aureus SAU 7 in a quantity of $1 \times 10^{10} \mathrm{cfu} / \mathrm{mL}$ (first constituent) and Str. agalactiae SAG 3 in a quantity of $4 \times 10^{9} \mathrm{cfu} / \mathrm{ml}$ (second constituent). By preparing the vaccine in the described manner 151 vaccine doses (5 mL each) were obtained.

\section{Vaccine sterility and toxicity tests}

To test for sterility the vaccine was seeded into 2 test tubes containing serum broth, 2 test tubes containing nutritious broth, Jansen's media with added starch and Jansen media with glucose added, nutritious oblique agar and blood agar. In none of the listed media aerobic or anaerobic bacterial growth was recorded. This proved that the vaccine was sterile. 
Toxicity was tested for on a total of 10 white mice, 2 guinea pigs, 4 sheep and 5 pregnant cows (Vakanjac et al., 2008).

\section{Citology}

The number of somatic cells was estimated by light miceoscopy, previously described by Vakanjac et al. (2008).

\section{Immunology tests}

Due to a lack of commercial ELISA tests special custom made tests for the purpose of the study were designed in order to determine the level of specific antibodies in the milk samples.

\section{Preparation of direct ELISA test plates}

The preparation of the antigen for ELISA consisted of Staphylococcus aureus SAU 7, and Streptococcus agalactiae SAG 3 vaccine strains, inoculated into $10 \mathrm{~mL}$ brain-heart broth (Oxoid, UK), and incubated at $37^{\circ} \mathrm{C}$ for 24 hours. After incubation, $2 \mathrm{~mL}$ broth culture was centrifuged at $6000 \mathrm{rpm}$ for $10 \mathrm{~min}$. The supernatant was discarded and the cell sediment resuspended in $2 \mathrm{~mL}$ phosphate buffered saline- PBS, pH 7.4 (Oxoid, UK). Thereon the suspensions were again centrifuged at $6000 \mathrm{rpm}$ for $10 \mathrm{~min}$ and the supernatant discarded. The procedure was repeated twice. The obtained sediments were resuspended in $5 \mathrm{~mL} 1 / 4$ Ringer solution (Oxoid, UK) with 2\% Lysosime (Merck, Germany), $89 \mathrm{mM}$ TRIS (Merck, Germany) and 2 mM EDTA (Merck, Germany) added. The solutions were incubated at $56^{\circ} \mathrm{C}$ for $30 \mathrm{~min}$. After incubation the solution was well mixed on a vortex mixer, and $0.3 \%$ formaldehyde was added (Merck, Germany). The suspension was incubated at $4^{\circ} \mathrm{C}$, for 24 hours. After incubation the suspension was heated in a thermoblock (Techne, Germany) at $100^{\circ} \mathrm{C}$ for $30 \mathrm{~min}$. Thereon the suspension was centrifuged at $6000 \mathrm{rpm}$ for $10 \mathrm{~min}$ and the supernatant was collected. The supernatant contained the antigens diluted 1:10 with the coating

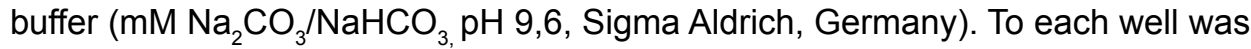
added $100 \mu \mathrm{L}$ coating buffer solution. The coated ELISA plates were incubated at $4^{\circ} \mathrm{C}$ for 24 hours. After incubation the plates were rinsed three times with the rinsing solution (PBS, $\mathrm{pH} 7.4$ ). To each of the wells $200 \mu \mathrm{L}$ of blocking buffer ( $3 \%$ casein hydrolysate/PBS, Oxoid, UK) was added. The blocked plates were incubated at $4^{\circ} \mathrm{C}$ for 24 hours. After incubation the plates were rinsed three times with the rinsing solution (PBS, $\mathrm{pH} 7.4$ ).

\section{Experiment}

Sixty pregnant dairy Holstein- Freesian cows of similar age (4-5 years) were included in the study. Experimental group 1 (E1) consisted of 20 cows, vaccinated two months prior to calving, and revaccinated a month before the expected term of delivery. Experimental group 2 (E 2) consisted of 20 cows vaccinated one month before and revaccinateed two months after calving. The remaining 20 
cows, considered as the control group (C), was vaccinated with a placebo vaccine (5 mL sterile saline).

Milk samples were taken from all animals before vaccination (before the dry period) and after calving at monthly intervals before the first symptoms of clinical and sub-clinical mastitis. The milk samples were tested cytologically and bacteriologically in order to disclose the presence of S. aureus and Str. agalactiae.

\section{RESULTS}

In this chapter the given results are from a farm with a high yearly incidence of sub-clinical and clinical mastitis where the cows were vaccinated and revaccinated with stable strains S. aureus SAU 7 and Str. agalactiae SAG 3.

\section{Microbiological testing}

The experiment lasted for 8 months, from the dry period, to the onset of clinical or subclinical mastitis caused by $S$. aureus and Str. agalactiae. Milk samples taken from the control group (C) and experimental group 2 (E2) at the start of the trial tested positive for $S$. aureus in 6 samples (40\%), and in experimental group 1 (E1) in 8 samples (53.3\%). At the end of the trial period $S$. aureus was isolated most often in the control group (53.3\%). Experimental group 1 (E1) exhibited 4 (26.6\%) and group 2 (E2) $3(20 \%)$ cows positive to $S$. aureus. Subclinical mastitis was diagnosed in 6 cows in the control group (40\%), followed by 4 cows $(26.6 \%)$ in the (E1), and in 3 cows (20\%) in the (E2). Clinical S. aureus mastitis emerged only in the control group in 2 cases (13.3\%). The cows from both experimental groups were not diagnosed with clinical mastitis (Table 1).

Table 1 Occurrence of clinical and subclinical mastitis, caused by $S$. aureus at the beginning and end of the experiment.

\begin{tabular}{|c|c|c|c|c|c|c|c|c|c|}
\hline Group & $\mathrm{n}$ & $\begin{array}{c}\text { S. aureus } \\
\text { start }\end{array}$ & $\%$ & $\begin{array}{c}\text { S. aureus } \\
\text { end }\end{array}$ & $\%$ & $\begin{array}{c}\text { Subclinical } \\
\text { mastitis }\end{array}$ & $\%$ & $\begin{array}{c}\text { Clinical } \\
\text { mastitis }\end{array}$ & $\%$ \\
\hline C & 15 & 6 & 40 & 8 & 53.3 & 6 & 40.0 & 2 & 13.3 \\
\hline E1 & 15 & 8 & 53 & 4 & 26.6 & 4 & 26.0 & $/$ & $/$ \\
\hline E2 & 15 & 6 & 40 & 3 & 20.0 & 3 & 20.0 & $/$ & $/$ \\
\hline
\end{tabular}

Table 2. Occurrence of clinical and subclinical mastitis caused by Str. agalactiae at the start and end of the trial

\begin{tabular}{|c|c|c|c|c|c|c|c|c|c|}
\hline Group & $\mathrm{N}$ & $\begin{array}{c}\text { S. agalactiae } \\
\text { start }\end{array}$ & $\%$ & $\begin{array}{c}\text { S. agalactiae } \\
\text { end }\end{array}$ & $\%$ & $\begin{array}{c}\text { Subclinical } \\
\text { mastitis }\end{array}$ & $\%$ & $\begin{array}{c}\text { Clinical } \\
\text { mastitis }\end{array}$ & $\%$ \\
\hline C & 15 & 3 & 20 & 2 & 13,3 & 2 & 13,3 & $/$ & $/$ \\
\hline E1 & 15 & 3 & 20 & $/$ & $/$ & $/$ & $/$ & $/$ & $/$ \\
\hline E2 & 15 & 3 & 20 & $/$ & $/$ & $/$ & $/$ & $/$ & $/$ \\
\hline
\end{tabular}


At the beginning of the experiment the milk samples from the control and (E1) and (E2), Str. agalactiae was isolated in $3(20 \%)$ of cows in each group. At the end of the experiment Str. agalactiae was isolated only in two cows $(13.3 \%)$ in the control group, while in the treated groups this microorganism was not isolated. Subclinical mastitis caused by Str. agalactiae was diagnosed in only two cows in the control group, while the causal agent was not isolated from cows from the vaccinated group. On the other hand, clinical mastitis caused by this microorganism was not diagnosed in any of the cows in the experiment (Table 2).

\section{Milk somatic cell count (SCC)}

The number of somatic cells (SCC) in $1 \mathrm{~mL}$ of milk was determined by cell counting under a light microscope by previously described means. The average value of SCC in $1 \mathrm{~mL}$ of milk obtained from cows in the control group (C) was $405215 \pm 41893$, while the value for (E1) was $613204 \pm 38123$, and for (E2) $527681 \pm 42617$. There was no statistical significance in the number of SCC during the entire period. In the control group of cows at the beginning of the dry period SCC was $972409 \pm 178844$ in $1 \mathrm{~mL}$ of milk, while (E1) and (E2) was $871011 \pm 122639$ and $946320 \pm 124567$, respectively. In the performed experiments, the average number of somatic cells in the milk samples in early lactation (colostrum) was for the control group $945609 \pm 170027$ in $1 \mathrm{~mL}$ of milk, in (E1) was $690317 \pm 114$ 126, and in (E2) SCC was $939356 \pm 114,175$ in $1 \mathrm{~mL}$ of milk. In the first month of the experiment the average number of SCC in $1 \mathrm{~mL}$ of milk was higher in the control group than in the treated groups (Figure 1). From the second month onward, the average number of SCC in $1 \mathrm{~mL}$ of milk in (E1) was greater than in the control (C) and (E2). After seven months, the

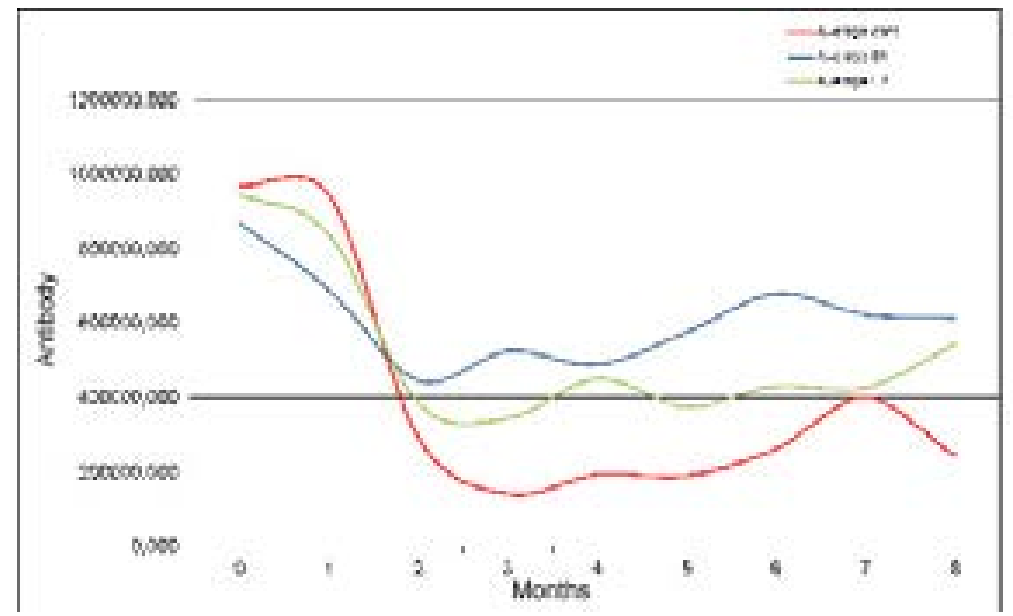

Figure 1. The average values of somatic cells (SCC) in $1 \mathrm{~mL}$ of milk 
average number of SCC in $1 \mathrm{~mL}$ of milk was lower in the control group (401 351 \pm 104 104), while in (E1 and E2) leveled at 623,507 $\pm 92,569$ and 626,555 \pm 113,386 in $1 \mathrm{~mL}$ of milk.

\section{Antibody milk titers}

Table 3 describes the percentages of clinical and subclinical $S$. aureus mastitis cases at the start and end of the experiment, as well as the anti staphylococcal antybodies titer in the milk samples of tested cows. The antistaphylococcal antibodies titer was lowest in the control group $(0.65 \pm 0.18 \mathrm{OD})$ and the incidence of cows affected with $S$. aureus increased from $40 \%$ to $53 \%$. Subclinical mastitis was diagnosed in 6 cows (40\%), and the clinical form was recorded in 2 animals (13\%). In the (E1) titer of anti staphylococcal antibodies was $0.78 \pm 0.21$, and the percentage of mastitis caused by $S$. aureus with reduced from $53 \%$ to $26.6 \%$. Subclinical mastitis was diagnosed in $4(26.6 \%)$ cows, and the clinical form caused by $S$. aureus was not diagnosed. The highest titers of staphylococcal antibodies was measured in the (E2) and amounted to $0.81 \pm$ 0.21 . The percentage of mastitis caused by $S$. aureus decreased from $40 \%$ to $20 \%$. Subclincal mastitis was diagnosed in 3 cows (20\%) and clinical mastitis caused by this microorganism was not reported.

Table 3. Incidence of subclinical and clinical mastitis and anti staphylococcal antibodies in the milk samples

\begin{tabular}{|c|c|c|c|c|c|c|}
\hline Group & $\mathrm{n}$ & $\begin{array}{c}\text { Incidence } \\
\text { of S. aureus } \\
\text { at the start } \\
\text { (number of } \\
\text { cows) }\end{array}$ & $\begin{array}{c}\text { Incidence } \\
\text { of S. aureus } \\
\text { at the end } \\
\text { (number of } \\
\text { cows) }\end{array}$ & $\begin{array}{c}\text { Subclinical } \\
\text { mastitis } \\
\text { (number of } \\
\text { cows) }\end{array}$ & $\begin{array}{c}\text { Clinical } \\
\text { mastitis } \\
\text { (number of } \\
\text { cows) }\end{array}$ & $\begin{array}{c}\text { Anti } \\
\text { staphylococal } \\
\text { antibody titres }\end{array}$ \\
\hline C & 15 & $40 \%(6)$ & $53.3 \%(8)$ & $40.0 \%(6)$ & $13.3 \%(2)$ & $0.65 \pm 0.18$ OD \\
\hline E1 & 15 & $53 \%(8)$ & $26.6 \%(4)$ & $26.6 \%(4)$ & $/$ & $0.78 \pm 0.21$ OD \\
\hline E2 & 15 & $40 \%(6)$ & $20.0 \%(3)$ & $20.0 \%(3)$ & $/$ & $0.81 \pm 0.21$ OD \\
\hline
\end{tabular}

Table 4 presents the percentages of subclinical and clinical mastitis caused by Str. agalactiae at the beginning and end of the experiment, and the antistreptococcal antibody titers in the milk samples. From the table we see that in the control group anti-streptococcal antibody titer was the lowest $(0.57 \pm 0.39 \mathrm{OD})$, and the percentage of mastitis caused by Str. agalactiae in the milk was reduced from $20 \%$ to $13.3 \%$. Subclinical mastitis was diagnosed in 2 cows (13.3\%) and clinical mastitis cases were not diagnosed. In (E1) streptococcal antibody titer was (1.00 $\pm 0.58 \mathrm{OD})$ and subclincal and clinical Str.agalactiae mastitis was not reported. The highest of streptococcal antibody titer was measured in (E2) and amounted to $1.11 \pm 0.64 \mathrm{OD}$, and subclinical and clinical mastitis cases were not reported in this group of animals. 
Table 4. Percentage of subclinical and clinical mastitis and anti-streptococcal antibody titer in the milk samples

\begin{tabular}{|c|c|c|c|c|c|c|}
\hline Group & $\mathrm{n}$ & $\begin{array}{c}\text { Incidence of } \\
\text { at agalactiae } \\
\text { (number } \\
\text { of cows) }\end{array}$ & $\begin{array}{c}\text { Incidence of } \\
\text { Str. agalactiae } \\
\text { at the end } \\
\text { (number } \\
\text { of cows) }\end{array}$ & $\begin{array}{c}\text { Subclinical } \\
\text { mastitis } \\
\text { (number } \\
\text { of cows) }\end{array}$ & $\begin{array}{c}\text { Clinical } \\
\text { mastitis } \\
\text { (number } \\
\text { of cows) }\end{array}$ & $\begin{array}{c}\text { Anti } \\
\text { staphylococal } \\
\text { antibody titres }\end{array}$ \\
\hline C & 15 & $20(3)$ & $13,3(2)$ & $13,3(2)$ & $/$ & $0.57 \pm 0.39$ OD \\
\hline E1 & 15 & $20(3)$ & $/$ & $/$ & $/$ & $1.00 \pm 0.58$ OD \\
\hline E2 & 15 & $20(3)$ & $/$ & $/$ & $/$ & $1.11 \pm 0.64$ OD \\
\hline
\end{tabular}

\section{DISCUSSION}

The tests have shown that the number of somatic cells (SCC) in the milk samples at the beginning of the dry period was approximately within the published literature data. In the control group SCC was $972409 \pm 178844$ in $1 \mathrm{~mL}$ of milk, in (E1) SCC was about $871011 \pm 122$ 639, while for (E2) SCC was $946319 \pm$ 124567 in $1 \mathrm{~mL}$ of milk. In the performed experiments the average number of somatic cells in early lactation was in the control group $945609 \pm 170$ 027, in (E1) was $690316 \pm 114$ 126, while for (E2) SCC was 936,356 $\pm 114,175$ in $1 \mathrm{~mL}$ of milk. Vakanjac et al. (2008) described an average SCC in the control group of $551.223 \pm 248.429$ cells $/ \mathrm{mL}$ and for the treated group was $582.022 \pm 297.312$ cells/ $\mathrm{mL}$ milk, this being very close to the values obtained in the here reported trial. The average value of SCC in $1 \mathrm{~mL}$ of milk in the control group was $405215 \pm 41$ 893, in experimental group 1 (E1) was $613204 \pm 38123$, while in experimental group 2 (E2) was $527681 \pm 42617$, indicating that between groups there was no significant increase in SCC. The results coincide with the results published by Nordhaug (1994), Giraudoa (1997), Hoedmaker (1999), Edinger (2000), Keskin (2007) and Prenafeta (2010), which did not report a significant increase in the number of SCC between groups.

During the entire experiment the values of the level of antibodies in experimental groups 1 and 2 were higher than for the control group. Mean value of specific staphylococcal antibodies in the control group was $0.650 \pm 0.18$, (E1) $0.78 \pm 0.21 \mathrm{OD}$, while the value in the (E2) was $0.81 \pm 0.21 \mathrm{OD}$. Values of specific staphylococcal antibody titer of the control group at the beginning of the experiment was $0.91 \mathrm{OD}$, but during the experiment the value decreased to 0.59 OD. Staphylococcal antibody titer was $1.01 \mathrm{OD}$ at the beginning of the experiment in the (E1), and during testing antibody levels decreased to $0.66 \mathrm{OD}$ in contrast to the level of antibodies in (E2), which at the beginning of the test was 0.99 . The lowest reported value during the trial period amounted to 0.72 OD.

Significantly higher levels of antibodies in the experimental group than in the control group throughout the experiment were reported by Nordhaug (1994), 
Loeffer (1987), Opdebeeck (1985), O’Brien (2000), Vakanjac (2008), Pellegrino (2008), Perez (2009) and others. Mean values of the titer of staphylococcal specific antibodies in the milk samples of (E2) were significantly higher compared to (E1), similar to the results of Watson (1992), Giraudo (1997) and Prenafeta (2010), who recommended this method of immunization of dairy cows. In experimental group 1 (vaccinated two months and revaccinated one month before expected calving) a higher level of anti staphylococcal antibodies was measured compared to the control group, but not when compared to (E2). The percentage of mastitis caused by $S$. aureus decreased from $53 \%$ to $26.6 \%$, with only subclinical mastitis diagnosed. Average level of anti-staphylococcal antibodies for group (E1) was $0.78 \pm 0.21 \mathrm{OD}$, compared to the control group $0.65 \pm 0.18 \mathrm{OD}$. The level of anti-staphylococcal antibodies in this group during the whole period of the experiment was lower than in group (E2). There was no statistical significance in the level of antibodies between groups (E1) and (E2) throughout the experiment, except in the fourth month from the start of the experiment. This is the period when a vaccine was administered to group (E2). Based on these results, we believe that this level of antibodies was sufficient to prevent the emergence of new staphylococcal infection, and decrease the number of mastitis cases by the end of the experiment. Nickerson (1999) in his work revealed similar results of an increased level of anti-staphylococcal antibodies and decreased occurrence of staphylococcal infection of the mammary gland, after vaccination and revaccination prior to calving. In experimental groups 1 and 2 , anti-streptococcal antibody levels increased significantly compared to the control group. Antibody level in the control group was $0.57 \pm 0.39 \mathrm{OD}$, (E1) $1.00 \pm$ 0.58 and (E2) $1.11 \pm 0.64 \mathrm{OD}$. Streptococcal mastitis was not reported in any of the experimental groups compared to the control where subclinical mastitis was diagnosed in $13.3 \%$ cows. The vaccine administered 45 days before and 60 days after parturition showed a significant increase in anti-staphylococcal and antistreptococcal antibodies in rabbits. Ahmad (2008) suggested the possibility that the bivalent vaccine reduced the occurrence of clinical and subclinical mastitis caused by S. aureus and Str. agalactiae. Abubakar (2006) points to a significant increase of anti-streptococcal antibodies in rabbits after multiple vaccinations in relation to a single vaccine application, prepared from inactivated bacterial cells of Str. agalactiae.

\section{CONCLUSIONS}

In cows vaccinated one month before and revaccinated two months after calving (experimental group 2), subclinical and clinical mastitis occurred in a significantly smaller percentage compared to the control cows. In both groups of vaccinated cows the number of somatic cells in the milk during the whole study period was higher than in the control group of cows, but this difference was not statistically significant. The concentration of immunoglobulin IgG in the milk of vaccinated cows was significantly higher than the concentration of this 
class of proteins in the milk of unvaccinated cows. Activation of humoral immune responses in cows vaccinated before and postpartum is far more pronounced than in cows that were vaccinated and revaccinated in the antepartal period.

\section{AKNOWLEDGEMENT}

This study was supported by the Ministry of Education and Science, Republic of Serbia within the interdisciplinary Project III 46002

Address for correspondence:

Dr, Vladimir Magaš, Lecturer

Faculty of Veterinary Medicine

University of Belgrade

Bul. oslobodjenja 18

11000 Belgrade

Serbia e mail:

\section{REFERENCES}

1. Abubakar M, Muhammad G, Ibrahim K, 2006, Primary and secondary immune response to formalin inactivited Streptococcus agalactiae isolates in rabits, Pakistan Vet J, 26, 3, 115-7.

2. Ahmad T, Muhammad G, 2008, Evaluation of Staphylococcus aureus and Streptococcus agalactiae aluminium hydroxide adjuvanted mastitis vaccine in rabbits, Pak J Agri Sci, 45, 2 353-61.

3. Calzolari A, Giraudo JA, Rampone H, Odierno L, Giraudo A, Frigerio $C$ et al., 1997, Field Trial of a Vaccine Against Bovine Mastitis. 2. Evaluation in two Commercial Dairy Herds, $J$ Dairy Sci, 80, 854-8.

4. Carter EW, Kerr DE, 2003, Optimization of DNA-based vaccination on Cows Using Green Fluorescent protein and Protein A as a Prelude to Immunization Against Staphylococcal mastitis, J Dairy Sci, 86, 1177-86.

5. Chen L, Li S, Wang Z, Chang R, Su J, Han B, 2012, Protective effect of recobinant staphylococcal enterotoxin A entrapped in polylactic-co-glycollic acid microspheres against Staphylococcus aureus infection, Vet Res, 43, 20 -31.

6. Edinger DB, Tenhagen BA, Baumgarrtner B, Heuwieser W, 2000, Efficacy of a herd specific vaccine against Staphylococcus aureus in dairy heifers, International Symposium on Immunology of Ruminant Mammary Gland, Stresa, 2000.

7. Giraudo JA, Calzolari A, Rampone H, Rampone A, Giraudo A, Bogni $C$ et al., 1997, Field Trial of a Vaccine Against Bovine Mastitis, 1. Evaluation in heifers, J Dairy Sci, 80, 845-53.

8. Hoedemaker M, Korff B, 1999, Untersuchungen zum Einsatz einer stallspezifischen Vakzine gegen Staphylococcus aureus in einem Milchviehbetrieb, Der praktische Tierarzt, collegium veterinarium $\mathrm{XXIX,68-71.}$

9. Keskin A, Seyrek-Intas K, Basri Tak H, Tuna B, Yilmazbas G, Ozakin C et al., 2007, Efficiency of Polyvalant Mastitis Vaccine in Lactanting Dairy Cows, J Biol Environ Sci, 1, 2, 87-92.

10. Lee J, O Brien C, Guidry AJ, Paape MJ, Shafer-Weaver KA, Zhao X, 2005, Effect of a trivent vaccine against Staphylococcus aureus mastitis lymphocyte subpopulations, antibody production, and neutrophil phagocytosis, Can J Vet Res, 69, 1,11-18.

11. Leitner G, Krifucks O, Kiran M, Balaban N, 2011, Vaccine development for the prevention of staphylococcal mastitis in dairy cows, Vet immunol Immunopathol, 142, 25-35.

12. Loeffer DA, Norcross NL, 1987, Use of enzyme-linked immunosorbent assay to measure bovine milk and serum antibodies to alpha toxin, beta toxin, and capsular antigens of Staphylococcus aureus, Vet immunol Immunopathol, 14, 145-56.

13. NickersonSC, Nickerson WE, Owens GM, Tomita PW, 1999, Vaccinating dairy heifers with 
a Staphylococcus aureus bacterin reduces mastitis at calving, Large Anim Pract, 20, 16-28.

14. Nordhaug ML, Nesse LL, Norcross NL, Gudding R, 1994, A Field Trial with an Experimental Vaccine Against Staphylococcus aureus Mastitis in Cattle, 1, Clinical Parameters, J Dairy Sci, 77, 1,1267-75.

15. O'Brien CN, Gudry AJ, Fattom A, Shepherd S, Douglass LW, Westhoff DC, 2000, Production of antibodies to Staphylococcus aureus serotypes 5, 8, and 336 using poly (DL-lacideco-glycolide) microspheres, J Dairy Sci, 83, 8, 1758-66.

16. Opdebeeck JP, Norcross NL, 1985, Antibodies in bovine serum and lactal secretions to capsular antigens of Staphylococcal aureus, Am J Vet Res, 46, 7, 1561.

17. Pellegrino M, Giraudo, Raspanti C, Nagel R, Odierno L, Primo $V$ et al., 2008, Experimental trial in heifers vaccinated with Staphylococcus aureus avirulent mutant against bovine mastitis, Vet microbiol, 127, 186 - 190.

18. Perez MM, Prenafeta A, Valle J, Penades J, Rota C, Solano C, Marco J et el, 2009, Protection from Staphylococcus aureus mastitis associated with poly-N-acetyl $\beta$ glucosamine specific antibody production using biofilm-embedded bacteria, Vaccine, 27, 2379-86.

19. Prenafeta A, March R, Casais I, Costa L, 2010, Study of the humoral immunogical response after vaccination with a Staphylococcus aureus biofilm-embedded bacterin in dairy cows: Possible role of the exopolysaccharide specific antibody production in the protection from Staphylococcus aureus induced mastitis, Vet immunol Immunopathol, 134, 3-4, 208-17.

20. Vakanjac Slobodanka, Pavlović M, Pavlović V, Obrenović Sonja, 2008, Immunoprophylaxis Staphylococcus aureus mastitis in dairy cows, Acta Veterinaria, 58, 2, 221-30.

21. Watson DL, McColl ML, Davies HI, 1996, Field trial of a staphylococcal mastitis vaccine in dairy herds, clinical, subclinical and microbiological assessments, AVJ, 447.

22. Watson $D L, 1992$, Vaccination against experimental staphylococcal mastitis in dairy heifers, Res Vet Sci, 53, 346-53.

\title{
OCENA EFIKASNOSTI BIVALENTNE VAKCINE U PROFILAKSI NASTANKA MASTITISA KOD KRAVA
}

\author{
MAGAŠ V, VAKANJAC SLOBODANKA, PAVLOVIĆ V, VELEBIT B, MIRILOVIĆ M, \\ MALETIĆ M, ĐURIĆ M I NEDIĆ SVETLANA
}

\section{SADRŽAJ}

Upala mlečne žlezde ili mastitis krava, predstavlja jedan od najaktuelnijih problema u intenzivnoj proizvodnji mleka. Dugogodišnji različiti pristupi lečenju mastitisa nisu dali odgovarajuće rešenje, pa je problem mastitisa i dalje prisutan i aktuelan. Sprečavanje prodora patogenog uzročnika u mlečnu žlezdu, njegovo naseljavanje i razmnožavanje, nameću stalnu potrebu za redovnom kontrolom mleka, kao i preduzimanje preventivnih i terapijskih mera u cilju smanjenja pojave nastanka mastitisa. Preventivna mera je i terapija krava u zasušenju koja podrazumeva lokalnu aplikaciju antibiotika nakon poslednje 
muže. Terapija krava u zasušenju treba u narednoj laktaciji da obezbedi što duži period neinficiranosti vimena, a obavezna je kod dijagnostikovanih subkliničkih mastitisa izazvanih sa Staphylococcus aureus i Streptococcus agalactiae. Radovi iz oblasti vakcinisanja preživara protiv uzročnika mastitisa ukazuju na ograničen uspeh u dobijanju značajnijih rezultata imunoprofilakse. S obzirom na rezultate drugih istraživača i sopstvenih preliminarnih istraživanja, a imajuću u vidu problem koji predstavljaju mastitisi uzrokovani Staphylococcus aureus-om i Streptococcus agalactiae, cilj istraživanja je bio priprema i ispitavanje autohtone vakcine pripremljene od dva štalska soja SAU 7 (S. aureus) i SAG 3 (Str. agalactiae). Broj somatskih ćelija u uzorcima mleka tokom celog trajanja ogleda je bio viši u obe ispitivane vakcinisane grupe, u odnosu na kontrolnu, ali nema statističke značajnosti. Koncentracija imunoglobulina IgG u mleku vakcinisanih krava je bila značajno povećana u odnosu na koncentraciju imunoglobulina nevakcinisane grupe. 